\title{
PENGEMBANGAN PERANGKAT PEMBELAJARAN FISIKA SMP BERBASIS SIMULASI VIRTUAL DAN KIT SEDERHANA DENGAN MODEL PEMBELAJARAN LANGSUNG DAN KOOPERATIF UNTUK MENGAJARKAN KETERAMPILAN PSIKOMOTOR DAN AFEKTIF PADA POKOK BAHASAN ALAT OPTIK
}

\author{
Suci Prihatiningtyas ${ }^{1)}$ \\ Tjipto Prastowo ${ }^{2)}$ \\ Budi Jatmiko ${ }^{3)}$
}

1) Mahasiswa Pendidikan Sains Pascasarjana Unesa

2) Dosen Prodi Pendidikan Sains Program Pascasarjana Unesa

3) Dosen Prodi Pendidikan Sains Program Pascasarjana Unesa e-mail:tea_ask_physics@yahoo.com

\begin{abstract}
The aim of this research is to develop learning physics based on virtual simulation and simple KIT by combined direct instruction and cooperative learning model device to teaches psychomotor and affective skills students at optical topic. The research subject is a physics instruction package that was developed using the 4-D model and applying One Group Pretest-posttest design for the test model. The study conducted in the second semester of the school year 2012/2013 at the class VIII MTs Kanjeng Sepuh Sidayu Gresik. The results showed that the validity of the instruction package in good categories and feasible to use in learning. The readability level of textbook is medium category, implementation of lesson study is good, Student activities are more dominant is the experiments with PhET simulations and simple KIT. Psychomotor learning outcomes after physics instruction package implemented is able to solve learning outcomes of students. For affective learning outcomes, students' social skills in working more dominant than ask and be a good listener. The response of the students towards learning is positive responses. Obstacles encountered during the learning is associated with time of learning and students' skills in presentation and discussion. Based on the findings above, it can be concluded that the instruction package developed feasible to use in learning to teache psychomotor and affective skills students at topic optical in junior high school.
\end{abstract}

Key words: virtual simulation, simple KIT, direct instruction, cooperative learning, Psychomotor, Affective Skills, Optical

\begin{abstract}
Abstrak: Penelitian ini adalah penelitian pengembangan (developmental research) yang bertujuan untuk mengembangkan perangkat pembelajaran berbasis simulasi virtual dan KIT sederhana dengan menggunakan model pembelajaran langsung dan kooperatif untuk mengajarkan keterampilan psikomotor dan afektif siswa pada pokok bahasan alat optik. Subjek penelitian ini adalah perangkat pembelajaran fisika berbasis simulasi virtual dan KIT sederhana dengan model pembelajaran langsung dan kooperatif pokok bahasan alat optik yang dikembangkan menggunakan model 4-D dengan model ujicoba One Group Pretest-Posttest Design. Penelitian dilakukan pada semester genap tahun ajaran 2012-2013 kepada siswa kelas VIII MTs Kanjeng Sepuh Sidayu Gresik. Hasil penelitian menunjukkan bahwa validitas perangkat pembelajaran berkategori baik. Tingkat keterbacaan buku ajar siswa termasuk dalam kategori sedang. Keterlaksanaan RPP berkategori baik. Aktivitas siswa yang dominan adalah kegiatan percobaan dengan simulasi PhET dan KIT sederhana. Hasil belajar psikomotor siswa setelah melalui tahap penerapan pembelajaran berbasis simulasi PhET dan KIT sederhana menggunakan model pembelajaran langsung dan kooperatif dapat menuntaskan hasil belajar seluruh siswa. Untuk hasil belajar afektif, kemampuan sosial siswa dalam bekerjasama lebih aktif. Respons siswa terhadap pembelajaran memberikan respons positif. Kendala yang dijumpai selama KBM berhubungan dengan alokasi waktu pelaksanaan KBM dan kemampuan siswa dalam presentasi serta diskusi. Berdasarkan hasil temuan di atas dapat disimpulkan bahwa perangkat yang dikembangkan layak digunakan dalam pembelajaran untuk mengajarkan keterampilan psikomotor dan afektif siswa.
\end{abstract}

Kata-kata Kunci: Simulasi Virtual, KIT Sederhana, Model Pembelajaran Langsung, Model Pembelajaran Kooperatif, Keterampilan Psikomotor, Afektif, Alat Optik

\section{PENDAHULUAN}

Pendidikan mempunyai peran penting dalam kemajuan suatu negara. Maju tidaknya pembangunan suatu negara pada masa yang akan datang dapat dilihat dari mutu pendidikan yang ada di negara tersebut. Oleh karena itu, pengembangan IPTEK dan kebutuhan masyarakat yang semakin meningkat, perlu diimbangi dengan peningkatan mutu pendidikan. Berbagai upaya telah dilakukan pemerintah untuk meningkatkan mutu pendidikan, misalnya melalui penataran guru-guru tentang proses belajar-mengajar, sertifikasi guru, dan penyempurnaan kurikulum 1984 menjadi kurikulum 2006 yaitu kurikulum 
tingkat satuan pendidikan (KTSP) (Adiarta, 2004).

Dalam KTSP untuk pendidikan dasar dan menengah disebutkan bahwa sains berfungsi untuk mengembangkan keterampilan wawasan dan kesadaran teknologi dalam kaitan dengan pemanfaatannya bagi kehidupan sehari-hari (Okta, 2011). Hal ini berarti, melalui pembelajaran sains di sekolah, semestinya dapat digunakan untuk membentuk kemampuan manusia yang utuh, dalam arti mempunyai sikap, kemampuan kognitif, dan keterampilan memecahkan permasalahan yang dihadapi. Sesuai dengan Peraturan Pemerintah Nomor 19 tahun 2005 Pasal 25 (4) tentang Standar Nasional Pendidikan dijelaskan bahwa kompetensi lulusan mencakup sikap, pengetahuan, dan keterampilan. Ini berarti bahwa pembelajaran dan penilaian harus mengembangkan kompetensi siswa yang berhubungan dengan ranah afektif (sikap), kognitif (pengetahuan), dan psikomotor (keterampilan).

Fisika merupakan salah satu cabang dari ilmu sains. Fisika merupakan hasil kegiatan manusia berupa pengetahuan, gagasan, dan konsep yang terorganisasi tentang alam sekitar yang diperoleh dari serangkaian pengalaman melalui proses ilmiah. Pelajaran fisika tidak cukup hanya mempelajari produk tetapi menekankan bagaimana produk itu diperoleh, baik sebagai proses ilmiah maupun pengembangan sikap ilmiah siswa. Untuk itu hasil belajar tidak hanya terbatas pada ranah kognitif, tetapi juga ranah psikomotor dan ranah afektif. Keterampilan psikomotor sangat penting untuk diajarkan karena dari keterampilan ini, siswa akan lebih mengetahui dan memahami apa yang telah mereka pelajari.

Berdasarkan informasi yang diperoleh peneliti dari angket yang diisi oleh siswa di MTs Kanjeng Sepuh Sidayu Gresik khususnya kelas VIII bahwa sebanyak 64\% siswa mengatakan guru tidak memanfaatkan laboratorium dalam rangka proses belajar mengajar dan $62 \%$ siswa mengatakan dalam satu semester guru mengajak melakukan praktikum kurang dari 2 kali. Hal ini mengakibatkan keterampilan psikomotor siswa rendah karena jarang dilatihkan. Guru lebih menitikberatkan pada pemberian materi tanpa ada praktikum sama sekali.

Berdasarkan angket, peneliti juga menemukan sebanyak $30 \%$ siswa belum terlibat aktif dalam pembelajaran, 35\% siswa belum terbiasa berpartisipasi, $45 \%$ siswa kurang aktif bertanya, 34\% pembagian tugas dalam kelompok belum terlaksana sehingga belum terjalin kerjasama dalam kelompok, 60\% siswa hanya menyimak dan mendengarkan informasi atau pengetahuan yang diberikan oleh guru dengan media papan tulis. Kondisi seperti ini mengakibatkan keterampilan sosial siswa belum timbul dalam proses pembelajaran. Kondisi seperti ini harus segera diperbaiki. Salah satu diantaranya melalui perbaikan kegiatan pembelajaran. Perbaikan pembelajaran ini meliputi perbaikan model pembelajaran dan tersedianya perangkat pembelajaran yang sesuai dengan model pembelajaran yang diterapkan sehingga diharapkan dapat mengajarkan keterampilan psikomotor dan afektif siswa. Arsyad (2006) mengemukakan dua unsur yang amat penting dalam proses pembelajaran di kelas yaitu model atau strategi dan media pembelajaran.

Pada pokok bahasan alat optik, materi pembiasan lensa positif sebagai prinsip utama untuk menjelaskan pembentukan bayangan pada alat optik seperti mata, kamera, lup, mikroskop, teropong, dan periskop. Untuk menjembatani dan mengembangkan kemampuan berpikir ilmiah pada diri siswa maka diperlukan model pembelajaran yang tepat. Model pembelajaran yang dianggap tepat untuk menyelesaikan permasalahan pembelajaran seperti yang disampaikan di atas adalah model pembelajaran langsung (MPL) dan kooperatif (MPK). Model pembelajaran langsung menekankan pada pengetahuan deklaratif dan prosedural. Pengetahuan deklaratif digunakan untuk menanamkan konsep pada siswa (ranah kognitif), sedangkan prosedural digunakan untuk mengajarkan keterampilan psikomotor siswa. Model pembelajaran kooperatif menekankan keterampilan sosial (afektif).

Selain penggunaan model pembelajaran yang bervariasi, pemilihan media pembelajaran juga diperhatikan. Dalam penelitian ini media yang digunakan berupa simulasi virtual dan KIT sederhana. Salah satu contoh simulasi virtual adalah simulasi Physics Education Technology (PhET). PhET adalah simulasi yang dibuat oleh University of Colorado yang berisi simulasi pembelajaran fisika, biologi, dan kimia untuk kepentingan pengajaran di kelas atau belajar individu. Simulasi PhET menekankan hubungan antara fenomena kehidupan nyata dengan ilmu yang mendasari, mendukung pendekatan interaktif dan konstruktivis, memberikan umpan balik, dan menyediakan tempat kerja kreatif (Finkelstein, 2006). Simulasi PhET yang akan peneliti gunakan adalah Geometric Optics. Kelebihan simulasi PhET dapat mengetahui jalannya sinar pada lensa hanya dengan menggeser-geser letak benda dan mengukur panjang lintasan letak benda sehingga dapat langsung mengetahui jarak bayangan dan sifat bayangan.

Pengetahuan fisika terdiri atas banyak konsep dan prinsip yang pada umumnya bersifat abstrak. Oleh karena itu, untuk memberi pemahaman siswa selain menggunakan simulasi PhET juga dilatihkan dengan menggunakan KIT sederhana. KIT sederhana adalah box yang berisi peralatan yang digunakan dalam praktikum tentang alat optik yang terdiri atas lensa positif bertangkai, rel presisi, pemegang slide diafragma dan diafragma anak panah, 
tumpukan berpenjepit serta layar. KIT sederhana merupakan media untuk menanamkan dan memantapkan pemahaman konsep-konsep fisika, menunjukkan hubungan antara konsep fisika dengan dunia sekitar serta aplikasi konsep dalam kehidupan nyata.

Banyak dijumpai pembelajaran yang berbasis simulasi dan KIT sederhana dengan menggunakan model pembelajaran langsung dan kooperatif memberikan manfaat yang cukup besar bagi siswa. Penelitian terkait dengan pengembangan perangkat pembelajaraan dengan media simulasi PhET dan KIT sederhana sudah pernah dilakukan sebelumnya yaitu penelitian mengenai: (1) Pengembangan perangkat pembelajaran berbasis media simulasi PhET dan KIT sederhana pada materi listrik dinamis oleh Samsuri (2010); (2) Pengembangan perangkat pembelajaran berbantuan multimedia PhET dan KIT sederhana pada pembelajaran fisika pokok bahasan alat-alat optik oleh Sugiono (2011). Kedua penelitian ini menyimpulkan bahwa pengembangan perangkat pembelajaran dengan menggunakan simulasi PhET dan KIT sederhana efektif diterapkan pada siswa SMA. Sedangkan penelitian yang terkait dengan model pembelajaran yaitu model pembelajaran langsung dan kooperatif dilakukan oleh Irianik (2010) tentang implementasi internet sebagai sumber belajar pada pembelajaran kimia pokok bahasan reaksi redoks menggunakan model pembelajaran langsung dan kooperatif dapat meningkatkan hasil belajar siswa.

Berdasarkan uraian di atas, maka timbul suatu pertanyaan: Apakah pengembangan perangkat pembelajaran berbasis simulasi virtual dan KIT sederhana dengan menggunakan model pembelajaran langsung dan kooperatif pada pokok bahasan alat optik dapat mengajarkan keterampilan psikomotor dan afektif siswa? Untuk mendapatkan jawaban, peneliti merencanakan mengadakan penelitian dengan judul "Pengembangan Perangkat Pembelajaran Fisika SMP Berbasis Simulasi Virtual dan KIT Sederhana dengan Model Pembelajaran Langsung dan Kooperatif untuk Mengajarkan Keterampilan Psikomotor dan Afektif Siswa pada Pokok Bahasan Alat Optik"

\section{METODE PENELITIAN}

Penelitian ini mengembangkan perangkat pembelajaran berbasis simulasi virtual dan KIT sederhana mengunakan model pembelajaran langsung dan kooperatif. Perangkat yang dikembangkan adalah RPP, BAS (buku ajar siswa), LKS, dan THB.

Pengembangan perangkat dalam penelitian ini menggunakan model 4D. Penggunaan model ini dalam pengembangan suatu mata pelajaran dimaksudkan agar (1) pada awal proses pembelajaran anak didik atau siswa dapat mengetahui dan mampu melakukan hal-hal yang berkaitan dengan materi pada akhir pembelajaran, (2) adanya pertautan antara tiap komponen khususnya media pembelajaran, model pembelajaran dan hasil pembelajaran yang dikehendaki, (3) menerangkan langkahlangkah yang perlu dilakukan dalam melakukan perencanaan desain pembelajaran, (4) mengajarkan keterampilan psikomotor dan afektif siswa.

Desain ujicoba perangkat pembelajaran dalam pengembangan perangkat ini menggunakan model pre eksperimen One Group Pretest-Posttest Design. Sebelum melaksanakan pembelajaran dilaksanakan tes awal (pretest) O1, dan setelah melaksanakan pembelajaran Guided Inquiry $\mathrm{X}$ dilakukan tes akhir (posttest) $\mathrm{O} 2$. Variabel yang diamati dalam penelitian adalah (1) Validitas RPP, LKS BA,S dan THB; (2) variabel yang berkaitan dengan hasil ujicoba perangkat pembelajaran meliputi: validitas perarngkat, keterbacaan BAS, keterlaksanaan RPP, aktivitas siswa, ketuntasan hasil belajar psikomotor dan afektif siswa, respons siswa dan kendala yang muncul dalam KBM.

Instrumen yang digunakan dalam penelitian ini adalah instrumen penilaian perangkat, instrumen pengmatan, instrument tes, dan instrument angket. Data yang dianalisis adalah validitas perangkat, keterbacaan BAS, keterlaksanaan RPP, aktivitas siswa, ketuntasan hasil belajar psikomotor dan afektif siswa, respons siswa dan kendala yang muncul dalam KBM dengan menggunakan teknik analisis deskriptif kulitatif dan deskriftif kuantitatif.

\section{HASIL PENELITIAN DAN PEMBAHASAN}

Perangkat yang dikembangkan dalam penelitian ini adalah RPP, LKS, BAS, dan THB. Berdasarkan ratarata nilai validasi kelayakan RPP dari dua validator sebesar 3,0 - 3,50 karena perangkat yang dikembangkan sesuai dengan tujuan pembelajaran, kegiatan pembelajaran, waktu, metode penyajian dan bahasa yang digunakan mudah dipahami oleh siswa. Rata-rata nilai koefisien reliabilitas lebih dari 90\%, yang berarti perangkat reliable (tingkat keajekan) dapat digunakan dimana saja akan mendapatkan hasil yang sama.

Perangkat yang juga membantu siswa dalam belajar adalah BAS. Perangkat ini disusun sesuai dengan standar kompetensi dan kebutuhan siswa. Hasil validasi perangkat BAS menunjukkan kategori baik $(3,0$ - 3,3) dengan realibilitas lebih dari $90 \%$ sehingga bisa dikatakan bahwa BAS valid dan reliabel. Hasil penilaian kelayakan LKS secara keseluruhan menunjukkan bahwa masing-masing validator memberikan hasil validasi baik dengan nilai antara 3,0-3,9. Hal ini dikarenakan LKS yang dikembangkan memiliki aspek petunjuk yang jelas, isi sesuai dengan materi yang diajarkan, prosedur kerja 
yang sistematis, kesesuaian pertanyaan dengan RPP dan sesuai dengan konsep yang diajarkan. Adapun nilai koefisien reliabilitas lebih dari 90\%. Hal ini menunjukkan bahwa LKS termasuk kategori baik sehingga valid dan layak digunakan Hasil penilaian THB masing validator memberikan nilai antara 3,2 - 3,8. Hal ini dikarenakan THB yang dikembangkan memiliki petunjuk yang jelas dalam pengerjaan soal, pokok soal dirumuskan dengan jelas, soal memberikan petunjuk ke arah jawaban yang benar, pilihan jawaban homogen, dan bahasa yang digunakan mudah dimengerti oleh siswa. Nilai koefisien reliabilitas lebih dari $90 \%$. Hal ini menunjukkan bahwa THB termasuk kategori baik sehingga layak digunakan.

Uji coba perangkat dilaksanakan di MTs Kanjeng Sepuh Sidayu Gresik. Hasil uji coba meliputi keterbacaan BAS, dan efektivitas pembelajaran.

\section{Keterbacaan BAS}

Keterbacaan BAS untuk kmasing-masing kelas replikasi dapat dilihat pada diagram batang pada Gambar 1 berikut.

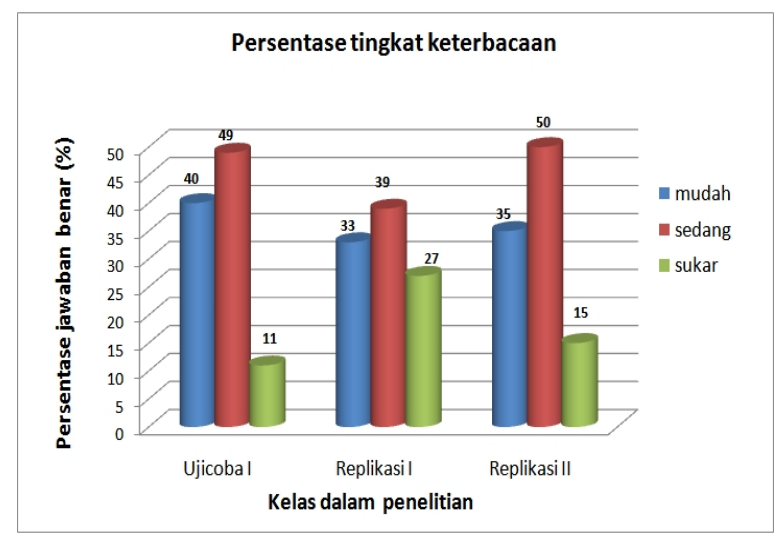

Gambar 1. Tingkat keterbacaan BAS untuk masing- masing kelas

Dari ketiga kelas ternyata dalam tiap-tiap kelas terdapat siswa yang masih memiliki tingkat keterbacaan rendah (sukar), sedang, dan tinggi (mudah) tetapi secara keseluruhan tingkat keterbacaan BAS termasuk kategori sedang. Perbedaan ini disebabkan karena siswa mempunyai karakteristik/kemampuan yang berbeda dalam membaca dan memahami BAS. Hal ini sejalan dengan pendapat Mc Laughnin (1980, dalam Kusmana 2008) bahwa keterbacaan berkaitan dengan pemahaman pembaca karena bacaannya memiliki daya tarik tersendiri yang memungkinkan pembaca terus tenggelam dalam bacaan. Keterbacaan berkaitan dengan tiga hal yaitu kemudahan, kemenarikan, dan keterpahaman.

\section{Keterlaksanaan RPP}

RPP disusun sesuai dengan jumlah pertemuan tatap muka untuk proses pembelajaran yaitu empat kali pertemuan. Setiap kali pertemuan dalam KBM, keterlaksanaan RPP diamati oleh dua pengamat yang mengamati berlangsungnya proses pembelajaran. Keterlaksanaan rencana pelaksanaan pembelajaran didasarkan atas pengelolaan Kegiatan Belajar Mengajar (KBM) meliputi pendahuluan, kegiatan inti, penutup, pengelolaan kelas (suasana kelas/antusias guru dan siswa), dan pengelolaan waktu (kesesuaian KBM dengan alokasi waktu). Untuk mendapatkan hasil yang efektif, persiapan merupakan hal yang paling penting, persiapan bagaimana materi dikemas, bagaimana setting pembelajaran dan media apa yang diperlukan (Sholikhakh, 2012).

Kegiatan pendahuluan sangat penting untuk menarik perhatian siswa. Pada kegiatan pendahuluan untuk ketiga kelas termasuk kategori baik dengan nilai rata-rata dari pengamat antara 3,6-4,0. Hal ini berarti guru sudah mampu membuka kegiatan pembelajaran dengan baik, guru mampu memotivasi siswa, mengaitkan pengetahuan awal yang dimiliki siswa, dan menyampaikan tujuan pembelajaran sehingga siswa mengerti dan memahami dengan apa yang akan mereka pelajari.

Pada kegiatan inti, pada ketiga kelas kemampuan guru dalam menyajikan informasi dan mendemonstrasikan pengetahuan atau keterampilan, mengorganisasikan siswa dalam kelompok-kelompok belajar, dan memberi latihan terbimbing pada siswa termasuk kategori baik karena nilai rata-rata pengamat untuk antara 3,6-4,0. Sedangkan kemampuan guru dalam membimbing kelompok bekerja dan belajar, mengarahkan diskusi, dan menyelenggarakan diskusi bernilai antara 3,0-3,5. Pembelajaran yang melibatkan siswa secara langsung, membuat siswa antusias dalam belajar. Hal ini dapat dilihat dari perhatian siswa yang tinggi terhadap penjelasan guru, menyelesaikan tugas yang diberikan oleh guru, dan aktif dalam kerja kelompok.

Untuk kegiatan penutup, termasuk kategori baik karena nilai rata-rata pengamat untuk ketiga kelas antara 3,6 - 4,0. Guru sudah mampu membimbing siswa dalam membuat kesimpulan dan guru memberikan penghargaan kepada kelompok yang hasil kerjanya baik, sehingga hal ini dapat memotivasi siswa untuk pembelajaran selanjutnya. Selanjutnya berkaitan dengan pengelolaan waktu, pada setiap pertemuan dikategorikan cukup baik dengan nilai rata-rata 3,0 - 3,5. Hal ini berarti $\mathrm{KBM}$ menggunakan simulasi PhET dan KIT sederhana dengan model pembelajaran langsung dan kooperatif mengalami kesulitan sehingga alokasi waktu tidak sesuai dengan yang telah direncanakan. Kegiatan ini tidak dapat berjalan sesuai dengan rencana karena jumlah siswa yang banyak, sehingga guru kesulitan dalam membimbing siswa pada saat percobaan dan diskusi sehingga waktu yang dibutuhkan relatif lama. 
Nilai rata-rata untuk suasana kelas untuk kelas replikasi I termasuk kategori baik karena pembelajaran terpusat pada siswa dan siswa antusias. Untuk kelas replikasi II dan III suasana kelas termasuk kategori cukup baik untuk pembelajaran yang terpusat pada siswa dan antusias guru tetapi untuk antusias siswa termasuk kategori baik. Hal ini menunjukkan bahwa selama KBM, guru mampu melibatkan siswa secara aktif dan menciptakan suasana kelas yang menyenangkan sehingga membuat siswa bersemangat belajar (pembelajaran berpusat pada siswa).

\section{Aktivitas siswa}

Hasil persentase aktivitas siswa yang dominan pada kelas replikasi I dan replikasi II adalah melakukan percobaan masing-masing $12,5 \%$. Sedangkan aktivitas siswa yang dominan pada kelas replikasi III adalah menyajikan data hasil percobaan $12,4 \%$. Belajar melalui pengamatan langsung dalam percobaan dapat memberikan keefektifan yang optimal dan ketuntasan belajar yang cukup (Mudakir, 2005).

Aktivitas siswa yang dominan dalam KBM didukung oleh beberapa teori yaitu Teori Piaget yang mengatakan bahwa guru dapat menciptakan suatu keadaan atau lingkungan belajar yang memadai agar siswa dapat menemukan pengalaman-pengalaman nyata dan terlibat langsung dengan alat dan media (simulasi PhET dan KIT sederhana).

\section{Ketuntasan hasil belajar psikomotor siswa}

Proporsi jawaban siswa untuk hasil belajar psikomotor secara keseluruhan dikatakan tuntas karena nilai yang mereka peroleh lebih dari KKM yaitu sebesar 72 . Persentase ketuntasan belajar siswa untuk kelas replikasi I, replikasi II, dan replikasi III sebesar 100\%. Begitupula ketika ditinjau berdasarkan ketuntasan individu pada semua kelas tuntas.

Menurut Taufiq (2008), simulasi PhET memberikan kesan yang positif, menarik, dan menghibur serta membantu penjelasan secara mendalam tentang suatu fenomena alam. Oleh karena itu, siswa yang berlatih simulasi PhET merasa senang dan mudah untuk mempelajarinya. Menurut Suhandi (2009), dengan penggunaan simulasi virtual pada pendekatan pembelajaran konseptual interaktif dapat lebih meningkatkan efektivitas dalam pemahaman konsep siswa dan meminimalkan miskonsepsi. Hal yang sama diungkapkan oleh Malik (2010), strategi Pembelajaran interaktif model simulasi merupakan strategi yang efektif, karena efektif dalam penggunaan waktu dan efektif dalam meningkatkan prestasi belajar mahasiswa. Lailiyah (2009) mengemukakan bahwa pembelajaran dengan menggunakan simulasi lebih efektif dibandingkan pembelajaran dengan demonstrasi dan ceramah. Hal ini menunjukkan bahwa pembelajaran dengan menggunakan simulasi dapat membantu siswa untuk lebih memahami persoalan yang dipelajari. Penggunaan KIT sederhana dalam pembelajaran juga berpengaruh dengan semangat belajar siswa. Hal ini didukung hasil penelitian bahwa penggunaan KIT dalam pembelajaran IPA di SMP dapat meningkatkan aktivitas belajar siswa.

\section{Ketuntasan hasil belajar afektif siswa}

Tes hasil belajar afektif (keterampilan sosial) digunakan untuk mengevaluasi kemampuan siswa dalam mengoptimalkan potensi tutor teman sebaya, dengan membentuk kelompok kecil yang heterogen kemampuannya, saling mengisi dan saling melengkapi. Persentase hasil belajar afektif keterampilan sosial untuk masing-masing kelas. Sikap siswa dalam bekerja sama untuk kelas replikasi I, replikasi II, replikasi III memiliki berkategori baik dengan persentase $69 \%, 70 \%$, dan $73 \%$.

Hal ini menandakan bahwa dengan menerapkan pembelajaran kooperatif, siswa mulai berinteraksi antara guru maupun teman sekelompoknya dengan baik. Hal ini sejalan dengan pendapat Hobri (2006) bahwa belajar kooperatif tidak hanya bertujuan memahamkan siswa terhadap materi yang akan dipelajari namun lebih menekankan pada melatih siswa untuk mempunyai keterampilan sosial yaitu kemampuan untuk saling bekerjasama, saling memahami, saling berbagi informasi, saling membantu antar teman kelompok, dan bertanggung jawab terhadap sesama teman kelompok untuk mencapai tujuan umum kelompok.

\section{Respon siswa}

Secara keseluruhan, siswa memberikan respons positif terhadap pembelajaran. Respons positif ini menunjukkan bahwa siswa antusias dengan pembelajaran yang disajikan. Hal ini dapat memotivasi siswa untuk meningkatkan perhatian dan membuat mereka terlibat dalam pengalaman pembelajaran yang menyenangkan dan bermakna (Nur, 2008). Motivasi ini yang mendorong siswa untuk melakukan aktivitas pembelajaran seperti yang teramati oleh pengamat, dengan intensitas yang cukup tinggi. Tingginya respons siswa secara tidak langsung dapat membantu siswa mendapatkan pemahaman konsep yang utuh.

\section{Kendala dalam KBM}

Kendala yang dijumpai selama KBM, siswa belum terbiasa dengan pembelajaran dengan menggunakan simulasi PhET dan KIT sederhana yang diimplementasikan dalam model pembelajaran langsung dan kooperatif, sehingga guru memerlukan waktu yang lama untuk menjelaskan kepada siswa tentang cara percobaan 
menggunakan simulasi PhET dan KIT sederhana, pada saat presentasi siswa cenderung monoton dan kurang siap, antara kelompok penyaji dengan kelompok yang menanggapi/mengajukan pertanyaan kurang siap, sehingga lebih banyak kelompok yang diam dan tidak bertanya/menanggapi presentasi kelompok yang maju, beberapa siswa menunjukkan perilaku yang tidak relevan dan belum menunjukkan karakter keterampilan sosial yaitu menjadi pendengar yang baik.

\section{Temuan}

Adapun rincian temuan-temuan tersebut adalah sebagai berikut:

1. Validitas perangkat pembelajaran berbasis simulasi virtual dan KIT sederhana dengan model pembelajaran langsung dan kooperatif pada pembelajaran fisika SMP pokok bahasan alat optik meliputi RPP, BAS, LKS, dan THB berkategori baik dan dapat digunakan dalam pembelajaran.

2. Tingkat keterbacaan buku ajar siswa termasuk dalam kategori sedang. Hal ini berarti pembaca berada pada tingkat instruksional yang artinya pembaca memerlukan bantuan untuk memahami isi bacaan.

3. Efektivitas perangkat pembelajaran dapat dilihat dari hasil temuan berikut:

a. Keterlaksanaan pembelajaran yang menggunakan simulasi virtual dan KIT sederhana dengan model pembelajaran langsung dan kooperatif telah berjalan dengan baik sesuai dengan RPP yang dikembangkan.

b. Aktivitas siswa selama KBM menunjukkan kategori baik, hampir seluruh siswa aktif mengikuti KBM. Aktivitas yang paling dominan adalah kegiatan percobaan dengan simulasi PhET dan KIT sederhana.

c. Hasil belajar psikomotor semua kelas tuntas, sedangkan untuk hasil belajar afektif, kemampuan sosial siswa dalam bekerjasama lebih aktif

d. Respons siswa terhadap pembelajaran memberikan respons positif.

e. Endala yang dijumpai selama KBM berhubungan dengan kemampuan siswa dalam presentasi dan diskusi, serta alokasi waktu pelaksanaan KBM.

\section{SIMPULAN}

Berdasarkan temuan tersebut, penelitian dapat disimpulkan bahwa pengembangan perangkat pembelajaran berbasis simulasi virtual dan KIT sederhana dengan model pembelajaran langsung dan kooperatif pada pokok bahasan alat optik yang diterapkan di MTs Kanjeng Sepuh Sidayu Gresik dinyatakan layak untuk digunakan dalam pembelajaran.

\section{DAFTAR PUSTAKA}

Adiarta, Agus dan Ni Ketut Rapi. 2004. "Implementasi strategi siklus belajar hipotesis-deduktif dengan peta konsep dalam pengubahan konseptual pada pembelajaran fisika". Jurnal Pendidikan dan Pengajaran IKIP Negeri Singaraja, No. $3 \mathrm{TH}$. XXXVII Juli 2004.

Arsyad, Azhar. 2011. Media Pembelajaran. Jakarta: PT. Rajagrafindo Persada.

Finkelstein, Noah. "Hightech Tools For Teaching Physics:The Physics Education Technology Project". Merlot journal of online learning and teaching. Vol. 2, No. 3, September 2006. 110-121.

Horbi dan Susanto. 2006. Penerapan pendekatan cooperative learning model group investigation untuk meningkatkan pemahaman siswa kelas III SLTPN 8 Jember tentang volume tabung. Jurnal pendidikan dasar, Vol 7, No. 2. $74-83$

Irianik, M. 2010. Implementasi internet sebagai sumber belajar pada pembelajaran kimia pokok bahasan reaksi redoks menggunakan model pengajaran langsung dan pembelajaran kooperatif. Tesis Magister Pendidikan Sains. Tidak dipublikasikan: Pascasarjana Universitas Negeri Surabaya.

Kusmana, Suherli. 2008. Keterbacaan buku teks pelajaran berdasarkan keterpahaman Bahasa Indonesia. Jurnal bahasa dan sastra. Vol 8 No 2. Oktober 2008. 122132.

Lailiyah, Eni. 2009. Perbandingan efektivitas metode simulasi javascript terhadap demonstrasi dan ceramah dalam meningkatkan kemampuan siswa untuk materi pemuaian dan wujud zat. Jurnal pembelajaran fisika sekolah menengah. Vol 1 No 1. Februari 2009. 9-13.

Nur, M. 2008. Model Pembelajaran Langsung. Surabaya: pusat sains dan matematika sekolah universitas negeri surabaya.

Malik, N. 2010. Pengaruh Strategi Pembelajaran Interaktif Model Simulasi Mata Kuliah Rangkaian Listrik Terhadap Hasil Belajar Mahasiswa Program Studi Pendidikan Teknik Elektro FT-UNM. Jurnal MEDTEK, Volume 2, Nomor 1, April 2010.

Mudakir, I. 2005. Keefektifan Penerapan Model SEQIP Dalam Pembelajaran Konsep Dasar IPA Di PGSD FKIP UNEJ. Jurnal Pendidikan Dasar.Vol.6, No.2, 2005: 61-118.

Okta, A. 2011. "Peningkatan Kualitas Pembelajaran IPA di SMP Melalui Pembelajaran Kontekstual". Bioedukasi. Vol. 2, no. 1.81-91.

Samsuri, 2010. Pengembangan Perangkat Pembelajaran Berbasis Media Simulasi PhET dan KIT Sederhana Pada Pembelajaran Fisika SMA Pokok Bahasan 
Listrik Dinamis. Tesis Magister Pendidikan Sains.

Tidak dipublikasikan: Pascasarjana Universitas

Negeri Surabaya.

Sholikhakh. 2012. "Pengembangan Perangkat Pembelajaran

Beracuan Konstruktivisme Dalam Kemasan CD

Interaktif Kelas VIII materi Geometri dan

Pengukuran". Unnes Journal Of Research

Mathematics Education. Juni 2012. 13-19.

Sugiono, Nanang. 2011. Pengembangan Perangkat Pembelajaran Berbantuan Multimedia PhET dan KIT Sederhana Pada Pembelajaran Fisika Pokok Bahasan Alat-alat Optik. Tesis Magister Pendidikan Sains. Tidak dipublikasikan: Pascasarjana Universitas Negeri Surabaya.

Suhandi. 2009. Efektivitas Penggunaan Media Simulasi Virtual Pada Pendekatan Pembelajaran Konseptual Interaktif Dalam Meningkatkan Pemahaman Konsep Dan Meminimalkan Miskonsepsi. Bandung.

Taufik, M. 2008. Pembuatan Media Pembelajaran Berbasis Compact Disc Untuk Menampilkan Simulasi Dan Virtual Labs Besaran-Besaran Fisika. J. Pijar MIPA. Vol. III No.3, September 2008: 68 - 72. 